\title{
Soil Physical and Chemical Properties in Epigeal Termite Mounds in Pastures
}

\author{
Sandra Santana de Lima ${ }^{1}$, Marcos Gervasio Pereira ${ }^{1}$, \\ Gilsonley Lopes dos Santos ${ }^{1}$, Rafael de Moura Pontes ${ }^{1}$, Anderson Ribeiro Diniz ${ }^{1}$ \\ ${ }^{1}$ Departamento de Solos, Universidade Federal Rural do Rio de Janeiro - UFRRJ, Seropédica/RJ, Brazil
}

\begin{abstract}
We characterized soil physical and chemical properties and soil organic matter in epigeal termite mounds in pastures to evaluate the changes promoted by termites in comparison to an adjacent area. We selected seven active epigeal termite mounds in the municipality of Seropédica, state of Rio de Janeiro, Brazil. Soil samples were collected from top, center and base positions of each mound, at 0.50 and $1.50 \mathrm{~m}$ distance from the base of the mound. We identified individuals of the genus Embiratermes, Velocitermes, and Orthognathotermes. The humin fraction predominated over the humic and fulvic acid fractions both in mounds and adjacent soil. The amount of organic matter and the mineral fractions (mineral-associated organic carbon - MOC) varied among builder species. The studied chemical attributes point to a higher concentration of nutrients in the mounds than in the adjacent soil.
\end{abstract}

Keywords: isoptera, humin fraction, nutrient cycling. 


\section{INTRODUCTION}

The invertebrate biota of the soil is considered important due to its participation in several soil processes. Some groups have special importance, such as termites, which are a dominant group in the tropical fauna (Constantino, 2002) both in open vegetation and tropical rainforests, where they play an important role in nutrient cycling and soil formation (Cancello \& Schlemmermeyer, 1999). Many species build large and complex mounds, which may harbor a rich associated fauna, including other termite species, arthropods, and even vertebrates (Constantino, 1999). Some types of termite mounds may reach high density (Lima-Ribeiro et al., 2006). The volume and the number of termite mounds vary considerably depending on the termite species and environmental conditions (Bezerra-Gusmão et al., 2011).

The activity of termites in the soil and the high density of their population have a significant effect on soil properties and processes (Holt \& Lepage, 2000). Termites transform the soil through faunal pedoturbation processes, such as the construction of galleries, tunnels, and mounds, where particles of minerals and organic matter are moved from different soil depths in large quantities (Jouquet et al., 2011; Adekayode \& Ogunkoya, 2009; Sarcinelli et al., 2009). Such activities result in changes in ecosystem dynamics through modification, maintenance, or creation of habitats for other organisms (Jouquet et al., 2006; Lavelle et al., 1997). Therefore, termites are considered "ecosystem engineers" (Jouquet et al., 2006; Dangerfield et al., 1998).

One of the main effects of termites on ecosystems is their role in the reduction of soil density and horizontal transport of materials through bioturbation, as well as the subsequent destruction of their constructions (Jouquet et al., 2011). After the destruction of the mound, the material of the termite mound is redistributed through erosion and affects soil fertility (Sarcinelli et al., 2009; Schaefer, 2001; Lee \& Wood, 1971). In addition, even active mounds can add nutrients to the soil (Rückamp et al., 2012).

The influence of termites is not restricted to their mounding and foraging area. The movement of material occurs both inside the mound and in the surrounding soil (Rückamp et al., 2012). Even species that do not ingest soil move particles because they mix soil particles with saliva with their mandibles to build their mounds (Sarcinelli et al., 2009). Estimates carried out based on the diameter and height of epigeal mounds show that, during mound construction, the termites transport large volumes of soil, which vary from 4-11 $\mathrm{m}^{3}$ ha $^{-1}$ (Oliveira et al., 2011) to $7.5 \mathrm{~m}^{3} \mathrm{ha}^{-1}$ year-1 or $13.0 \mathrm{t} \mathrm{ha}^{-1}$ year $^{-1}$ of soil from deeper layers to the surface (Sarcinelli et al., 2009). These estimates corroborate the role of termites in the transport of material that results in changes in soil properties.

The impact of termites on the soil chemical properties is poorly known, especially considering different mound sections (top, center, and base) compared to the adjacent soil. Sarcinelli et al. (2009) compared internal sections of epigeal mounds with samples of adjacent areas and assessed their physicochemical properties. Oliveira et al. (2012) assessed changes in physicochemical properties of epigeal mounds compared to soil samples of adjacent areas as well. These authors considered a mound subdivided in top, center, and base and compared it to the adjacent soil within a radius of $1.5 \mathrm{~m}$ from the base of the epigeal mound. Pinheiro et al. (2013) also carried out studies considering mound sections and assessed the chemical and biological properties of the material, but they did not report the distance from the base of the epigeal mound where they sampled the soil. In spite of the differences in the properties assessed, as well as in the distance from the base of the mound where samples were collected, all authors reported differences between the mound and the surrounding soil. However, it is important to advance the knowledge of these alterations and their extension to the soil surface. The objective of the present study was to characterize the physical and chemical soil properties and the organic matter of termite epigeal mounds in a pasture and to evaluate the changes made by termites compared to an adjacent area.

\section{MATERIAL AND METHODS}

The study area was a 1-ha pasture on a Planossolo Háplico (Santos et al., 2013) located in the municipality of Seropédica in the campus of the Federal Rural University of Rio de Janeiro (UFRRJ) (22 $46^{\prime} 59^{\prime \prime}$ S, $43^{\circ} 40^{\prime} 45^{\prime \prime} \mathrm{W}$, at $33 \mathrm{~m}$ a.s.l.). The climate of the region is Aw in Köppen's classification, characterized by two well-defined seasons: a cold and dry season from 
April to September and a warm and rainy season from October to March.

In the first fortnight of November 2012, we picked up mounds randomly, observing mound vigor. We broke the mound partially with an iron digger tool in the search for termites. In seven mounds, we collected soil samples at 0.50 and $1.50 \mathrm{~m}$ distance from the base of each mound and at the 0.0-0.05 and 0.05-0.10 m soil layers. Four composite samples per mound were obtained. In the epigeal part of the mound, samples were taken from top, center, and base sections following that sequence. Each sample consisted of material from the external and internal sections of the mound. During sampling, we collected termites of several species and all castes and placed them in alcohol $80 \%$. Specimens were identified at genus level using taxonomic keys (Constantino, 1999; Cancello, 1989; Mathews, 1977). Soil and mound samples were air dried, grounded and sieved through 2-mm mesh sieves, to perform physical and chemical analysis following Donagema et al. (2011) methods.

\subsection{Soil physical and chemical analysis}

Particle size analysis of soil and mound samples was performed by the Pipette method, and $\mathrm{pH}$ in water in the ratio 1: 2.5 (soil: water); $\mathrm{Ca}^{+2}$ and exchangeable $\mathrm{Mg}^{+2}$ extracted with $\mathrm{KCl} 1 \mathrm{~mol} \mathrm{~L}^{-1}$ were analyzed by titration; $\mathrm{P}$ and $\mathrm{K}^{+}$extracted by the Mehlich- 1 method were analyzed by colorimetry $(\mathrm{P})$ and flame photometry $\left(\mathrm{K}^{+}\right)$Donagema et al. (2011). We characterized organic matter through grain-size fractionation (Cambardella \& Elliott, 1992) and by chemical fractionation (Swift, 1996), following a modified technique from Benites et al. (2003).

\subsection{Statistical analyses}

The averages of treatments (top, center, base, distance 0.50 and $1.50 \mathrm{~m}$ ) were statistically analyzed using a fully randomized design, and the Lilliefors and Cochran and Bartlet tests were used to assess normality and homogeneity of variance, respectively, in the SAEG 5.0 software (Ribeiro, 2001). After verification of attendance to assumptions, the data were submitted to an analysis of variance (ANOVA), and the average values were compared with a Bonferroni t test ( $\alpha=5 \%$ ) in the SISVAR software (Ferreira, 2008).

\section{RESULTS AND DISCUSSION}

\subsection{Termite identification}

The structure of the mounds was homogeneous in terms of construction material, i.e., we did not observe inside them a more friable internal section, also named carton, in comparison to an external harder section. We identified individuals of the genera Embiratermes (three mounds), Velocitermes (two mounds), and Orthognathotermes (two mounds), one of which cohabited the mound with Embiratermes. These genera are commonly observed cohabiting in mounds within pastures of other builder species, such as Cornitermes snyderi and Cornitermes cumulans (Lima et al., 2011; Cunha \& Morais 2010), but only Orthognathotermes does not build mounds (Constantino, 1999).

Only mounds habited by termites of the genus Velocitermes were particularly friable, and therefore easily breakable. According to Oliveira (2013), Velocitermes heteropterus is an exception in terms of how this species builds mounds, as other species in diffuse galleries in the soil or in termite mounds of other species, especially of the genus Cornitermes.

\subsection{Texture}

Soil particle size distribution in mounds showed similar clay concentration on top, center, and base sections. In change, clay concentration was significantly $(\mathrm{P}<0.05)$ higher in mounds than in samples of adjacent soil for all depths and distances (Table 1). The total sand fraction did not differ among mound sections either, but the mounds showed significantly $(\mathrm{P}<0.05)$ lower sand contents (mainly fine and coarse fractions) than the adjacent soil, with no differences between distances. Slightly, although significantly $(\mathrm{P}<0.05)$ higher sand contents were observed in the center of mounds, with greater differences from mound to adjacent soil at the 0.0-0.05 m soil layer.

The coarse sand fraction did not differ among mound sections, but mound sections showed smaller values than the adjacent soil, at the $0.05-0.10 \mathrm{~m}$ soil layer and at both sampling distances (Table 1). This may indicate a selection of smaller particles by moundbuilding termites. In pastures of the state of Tocantins, Oliveira et al. (2012) also observed higher clay contents in mounds of the genus Procornitermes. Unlike them, 
Table 1. Composition of termite mounds and adjacent soil.

\begin{tabular}{|c|c|c|c|c|c|c|}
\hline \multirow{2}{*}{ Treatments } & Clay & Total sand & Fine sand & Coarse sand & Silt & \multirow{2}{*}{ Texture class } \\
\hline & \multicolumn{5}{|c|}{$\mathrm{g} \mathrm{kg}^{-1}$} & \\
\hline \multicolumn{7}{|c|}{ Depth $0.0-0.05 \mathrm{~m}$} \\
\hline Top & $362 a$ & $354 \mathrm{~b}$ & $174 \mathrm{c}$ & $180 \mathrm{bc}$ & $283 a$ & Clay-loam \\
\hline Center & $364 a$ & $365 \mathrm{~b}$ & $182 \mathrm{bc}$ & $181 \mathrm{bc}$ & $271 \mathrm{a}$ & Clay-loam \\
\hline Base & $381 \mathrm{a}$ & $333 \mathrm{~b}$ & $165 c$ & $167 c$ & $285 \mathrm{a}$ & Clay-loam \\
\hline $50 \mathrm{~cm}$ & $238 \mathrm{~b}$ & $464 \mathrm{a}$ & $248 \mathrm{a}$ & $215 \mathrm{ab}$ & $297 \mathrm{a}$ & Loam \\
\hline $150 \mathrm{~cm}$ & $295 \mathrm{ab}$ & $451 \mathrm{a}$ & $248 \mathrm{ab}$ & $225 \mathrm{a}$ & $252 \mathrm{a}$ & Sandy-clay-loam \\
\hline $\mathrm{CV} \%$ & 19.11 & 10.66 & 15.15 & 13.79 & 18.55 & \\
\hline \multicolumn{7}{|c|}{ Depth $0.05-0.10 \mathrm{~m}$} \\
\hline Top & $362 \mathrm{a}$ & $354 \mathrm{~b}$ & $174 \mathrm{bc}$ & $180 \mathrm{~b}$ & $281 \mathrm{a}$ & Clay-loam \\
\hline Center & $364 \mathrm{a}$ & $364 b$ & $182 \mathrm{abc}$ & $181 \mathrm{~b}$ & $271 \mathrm{a}$ & Clay-loam \\
\hline Base & $381 \mathrm{a}$ & $332 \mathrm{~b}$ & $165 \mathrm{c}$ & $167 \mathrm{~b}$ & $285 \mathrm{a}$ & Clay-loam \\
\hline $50 \mathrm{~cm}$ & $275 b$ & $478 \mathrm{a}$ & $217 \mathrm{ab}$ & $261 \mathrm{a}$ & $245 \mathrm{a}$ & Sandy-clay-loam \\
\hline $150 \mathrm{~cm}$ & $290 \mathrm{~b}$ & $472 \mathrm{a}$ & $227 \mathrm{a}$ & $245 \mathrm{a}$ & $237 \mathrm{a}$ & Sandy-clay-loam \\
\hline CV\% & 10.8 & 10.66 & 13.88 & 14.83 & 14.21 & \\
\hline
\end{tabular}

Mean values (7 replicate) followed by the same letter within columns are not significantly different according to Bonferroni test $(\mathrm{P}<0.05)$.

Kaschuk et al. (2006) observed similar clay contents in mounds of Cornitermes cumulans, Cortamitermes fuviceps, and Neocarpritermes opacus, and the adjacent soil in a study conducted in the state of Santa Catarina.

A higher concentration of clay in mounds in comparison with the adjacent soil is probably the result of the preference of termites for finer particles as cement for building their mounds (Donovan et al., 2001). In our study, clay and sand seemed to be used almost in the same proportion, whereas silt was used in lower proportion. This is a different pattern than that found by Oliveira et al. (2012), who observed higher proportions of sand and silt than that of clay in the mounds. This difference is probably explained by the builder species which determine the material used, however, assertions related to particle size are still scarce.

\subsection{Characterization of the sorption complex}

Soil $\mathrm{pH}$ values were significantly $(\mathrm{P}<0.05)$ higher on the top of mounds than on their base sections. This could influence the adjacent soil at the $0.0-0.05 \mathrm{~m}$ layer. This fact is also evidenced by the $\mathrm{pH}$-values at the depth of 0.05-0.10 $\mathrm{m}$ (Table 2). The influence of the mound on soil acidity is also shown by $\mathrm{Al}^{+3}$ concentrations in accordance with the $\mathrm{pH}$ values. The higher acidity of the base is in agreement with a higher percentage of $\mathrm{Al}^{+3}(\mathrm{P}<0.05)$ (Table 2). Oliveira et al. (2012) also observed higher $\mathrm{pH}$ values on the tops of termite mounds.

We did not observe significant differences in $\mathrm{Ca}^{+2}$ content among mound sections, but $\mathrm{Ca}^{+2}$ values were higher in the mounds $(\mathrm{P}<0.05)$ than in the adjacent soil. However, there was a similarity in $\mathrm{Ca}^{+2}$ values between the mound and the adjacent soil at $0.50 \mathrm{~m}$ from the mound at both depths, which could indicate an influence of the mound on the soil. At a distance of $1.50 \mathrm{~m}$, though, the $\mathrm{Ca}^{+2}$ values were significantly lower than those of the mound sections (Table 2). We observed a small difference in $\mathrm{Mg}^{+2}$ and $\mathrm{K}^{+}$contents $(\mathrm{P}<0.05)$ among mound sections; $\mathrm{Mg}^{+2}$ values were higher in the center, whereas $\mathrm{K}^{+}$values were higher in the base (Table 2). We observed a similarity in the content of these nutrients in the adjacent soil, which indicates a possible influence of the mound at $0.0-0.05 \mathrm{~m}$ below ground and at $0.50 \mathrm{~m}$ from the termite mound. $\mathrm{K}^{+}$is easily translocated, and although $\mathrm{Mg}^{+2}$ does not have the same mobility as $\mathrm{K}^{+}$, it showed the same pattern. Our results are similar to those observed by Oliveira et al. (2012) and Sarcinelli et al. (2009). Other authors who studied the influence of mounds of Trinervitermes on soil fertility in Burkina Faso, western Africa, have also observed that the values of exchangeable cations $\left(\mathrm{Ca}^{+2}, \mathrm{Mg}^{+2}\right.$ and $\left.\mathrm{K}^{+}\right)$changed in the adjacent soil, with an enrichment in $\mathrm{Mg}^{+2}$ and $\mathrm{K}^{+}$contents and lower values of $\mathrm{Ca}^{+2}$ (Brossard et al., 2007). 
Table 2. Chemical attributes of termite mounds and adjacent soil in a pasture.

\begin{tabular}{|c|c|c|c|c|c|c|c|c|c|c|}
\hline \multirow{2}{*}{ Treatments } & \multirow{2}{*}{ pH } & $\mathrm{Al}^{+3}$ & $\mathbf{H}+\mathbf{A l}$ & $\mathrm{Ca}^{+2}$ & $\mathbf{M g}^{+2}$ & $\mathbf{K}^{+}$ & S Value & T Value & $\% \mathrm{Al}$ & $\mathbf{P}$ \\
\hline & & \multicolumn{8}{|c|}{$\mathrm{cmolc} \mathrm{kg}^{-1}$} & $\mathrm{mg} \mathrm{kg}^{-1}$ \\
\hline & \multicolumn{10}{|c|}{ Depth 0.0-0.05 m } \\
\hline Top & $5.5 \mathrm{a}$ & $0.2 \mathrm{c}$ & $10.22 \mathrm{ab}$ & $1.32 \mathrm{a}$ & $1.87 \mathrm{ab}$ & $0.03 \mathrm{ab}$ & $3.39 \mathrm{a}$ & $13.61 \mathrm{a}$ & $6.71 \mathrm{~b}$ & $17.98 \mathrm{a}$ \\
\hline Center & $5.2 \mathrm{ab}$ & $0.3 \mathrm{bc}$ & $11.49 \mathrm{a}$ & $1.32 \mathrm{a}$ & $2.21 \mathrm{a}$ & $0.03 \mathrm{ab}$ & $3.70 \mathrm{a}$ & $16.21 \mathrm{a}$ & $9.28 \mathrm{~b}$ & $19.90 \mathrm{a}$ \\
\hline Base & $4.8 \mathrm{~b}$ & $0.9 \mathrm{ab}$ & $13.02 \mathrm{a}$ & $1.17 \mathrm{a}$ & $1.87 \mathrm{ab}$ & $0.04 \mathrm{a}$ & $3.19 \mathrm{a}$ & $15.20 \mathrm{a}$ & $26.14 \mathrm{ab}$ & $21.02 \mathrm{a}$ \\
\hline $50 \mathrm{~cm}$ & $4.9 \mathrm{ab}$ & $0.7 \mathrm{abc}$ & $6.75 \mathrm{~b}$ & $0.68 \mathrm{ab}$ & $1.22 \mathrm{bc}$ & $0.02 \mathrm{bc}$ & $2.03 \mathrm{~b}$ & $8.78 \mathrm{~b}$ & $24.42 \mathrm{ab}$ & $5.06 \mathrm{~b}$ \\
\hline $150 \mathrm{~cm}$ & $5.2 \mathrm{ab}$ & $1.0 \mathrm{a}$ & $6.52 \mathrm{~b}$ & $0.45 \mathrm{~b}$ & $1.07 \mathrm{c}$ & $0.01 \mathrm{c}$ & $1.62 \mathrm{~b}$ & $8.15 b$ & $38.71 \mathrm{a}$ & $2.96 \mathrm{~b}$ \\
\hline \multirow[t]{2}{*}{ CV\% } & 8.14 & 60.43 & 25.86 & 41.68 & 27.67 & 39.67 & 24.84 & 22.33 & 56.17 & 30.91 \\
\hline & \multicolumn{10}{|c|}{ Depth $0.05-0.10 \mathrm{~m}$} \\
\hline Top & $5.5 \mathrm{a}$ & $0.2 \mathrm{~b}$ & $10.22 \mathrm{ab}$ & $1.33 \mathrm{a}$ & $1.87 \mathrm{ab}$ & $0.03 \mathrm{ab}$ & $3.18 \mathrm{a}$ & $13.60 \mathrm{a}$ & $6.71 \mathrm{~b}$ & $17.97 \mathrm{a}$ \\
\hline Center & $5.2 \mathrm{ab}$ & $0.3 \mathrm{~b}$ & $11.49 \mathrm{a}$ & $1.33 \mathrm{a}$ & $2.21 \mathrm{a}$ & $0.04 \mathrm{a}$ & $3.70 \mathrm{a}$ & $15.20 \mathrm{a}$ & $9.28 \mathrm{~b}$ & $19.90 \mathrm{a}$ \\
\hline Base & $4.8 \mathrm{~b}$ & $0.9 \mathrm{a}$ & $13.02 \mathrm{a}$ & $1.17 \mathrm{a}$ & $1.87 \mathrm{ab}$ & $0.04 \mathrm{a}$ & $3.18 \mathrm{a}$ & $16.21 \mathrm{a}$ & $26.14 \mathrm{a}$ & $21.03 \mathrm{a}$ \\
\hline $50 \mathrm{~cm}$ & $5.4 \mathrm{a}$ & $0.6 \mathrm{ab}$ & $6.66 \mathrm{~b}$ & $0.72 \mathrm{ab}$ & $1.23 \mathrm{c}$ & $0.03 \mathrm{ab}$ & $2.06 \mathrm{~b}$ & $8.73 \mathrm{~b}$ & $21.71 \mathrm{ab}$ & $4.54 \mathrm{~b}$ \\
\hline $150 \mathrm{~cm}$ & $5.3 \mathrm{ab}$ & $0.9 \mathrm{a}$ & $6.23 \mathrm{~b}$ & $0.45 \mathrm{~b}$ & $1.27 b c$ & $0.01 \mathrm{~b}$ & $1.85 \mathrm{~b}$ & $8.08 \mathrm{~b}$ & $33.43 \mathrm{a}$ & $2.41 \mathrm{~b}$ \\
\hline CV\% & 7.03 & 53.63 & 26.2 & 42.37 & 22.47 & 46.82 & 23.2 & 22.69 & 49.61 & 32.15 \\
\hline
\end{tabular}

Mean values (7 replicate) followed by the same letter within columns are not significantly different according to Bonferroni test $(\mathrm{P}<0.05)$

Phosphorus did not differ among mound sections, but it was the nutrient that most differed between the termite mound and the adjacent soil, with higher values in the mound than in the soil. Although there was no significant difference, the $\mathrm{P}$ values at the distance of $0.50 \mathrm{~m}$ were almost the double of the values at $1.50 \mathrm{~m}$ from the mound, which indicates the influence of the mound on its adjacent soil (Table 2). Rückamp et al. (2010) quantified and systematized phosphorus forms in different sections of termite mounds (exterior wall, internal wall, and center) of different trophic guilds and soils in seven Brazilian ecosystems and concluded that termite activity results in a gross enrichment of phosphorus in labile form in nets, and the composition of $\mathrm{P}$ in termite constructions is reflected in their diet. According to Oliveira et al. (2012), the higher amount of $\mathrm{P}$ in termite mounds than in the adjacent soil is related to the amount of clay used in their construction, which hinders the loss of $\mathrm{P}$ available.

\subsection{Total organic carbon and grain-size fractionation of soil organic matter (SOM)}

Total organic carbon (TOC) values observed in termite mound sections varied from 20.56 to $21.37 \mathrm{~g} \mathrm{~kg}^{-1}$, which did not differ from each other or from the adjacent soil (Table 3). The mounds occupied by the termites of the genus Embiratermes had a homogeneous structure, which was denser than those occupied by Velocitermes; both mounds showed no central area and material
Table 3. Total organic carbon (TOC), particulate organic carbon (POC), and mineral-associated organic carbon (MOC) of termite mounds and adjacent soil in a pasture area.

\begin{tabular}{cccl}
\multirow{2}{*}{ Treatment } & TOC & POC & MOC \\
\cline { 2 - 4 } & \multicolumn{4}{c}{ g kg $^{-1}$} \\
Top & $20.56 \mathrm{a}$ & $24.99 \mathrm{a}$ & $28.17 \mathrm{ab}$ \\
\hline Center & $21.08 \mathrm{a}$ & $27.82 \mathrm{a}$ & $33.29 \mathrm{a}$ \\
\hline Base & $21.37 \mathrm{a}$ & $27.86 \mathrm{a}$ & $31.40 \mathrm{a}$ \\
\hline $50 \mathrm{~cm}$ & $18.72 \mathrm{a}$ & $18.12 \mathrm{a}$ & $20.02 \mathrm{bc}$ \\
\hline $150 \mathrm{~cm}$ & $18.19 \mathrm{a}$ & $14.67 \mathrm{a}$ & $19.06 \mathrm{c}$ \\
\hline CV\% & 18.19 & 47.21 & 20.62 \\
\hline \multicolumn{4}{c}{ Depth $0.05-0.10 \mathrm{~m}$} \\
\hline Top & $20.56 \mathrm{a}$ & $24.99 \mathrm{a}$ & $28.17 \mathrm{ab}$ \\
\hline Center & $21.08 \mathrm{a}$ & $27.82 \mathrm{a}$ & $33.29 \mathrm{a}$ \\
\hline Base & $21.37 \mathrm{a}$ & $27.86 \mathrm{a}$ & $31.40 \mathrm{a}$ \\
\hline $50 \mathrm{~cm}$ & $20.40 \mathrm{a}$ & $16.96 \mathrm{a}$ & $17.27 \mathrm{c}$ \\
\hline $150 \mathrm{~cm}$ & $17.46 \mathrm{a}$ & $15.92 \mathrm{a}$ & $18.85 \mathrm{bc}$ \\
\hline CV\% & 22.46 & 45.71 & 23.41 \\
\hline
\end{tabular}

Mean values ( 7 replicate) followed by the same letter within columns are not significantly different according to Bonferroni test $(\mathrm{P}<0.05)$.

accumulation, which would consequently result in a higher content of organic carbon. The results observed in the present study differ from Sarcinelli et al. (2009), who observed a higher carbon content in the mounds of Cornitermes than in the adjacent soil. This difference may be related to the builder species: the mounds of Cornitermes are characterized by a friable part in 
their interior (carton) and have high organic carbon values. Many authors have observed higher carbon concentration inside mounds than in the adjacent soil (Bezerra-Gusmão et al., 2011; Sarcinelli et al., 2009; Holt \& Lepage, 2000; Lee \& Wood, 1971), and also between the soil below and surrounding the mound (Rückamp et al., 2012).

The values of particulate organic carbon (POC) did not differ among mound sections. This similarity was also observed between mounds and adjacent soil at both depths. However, the high values of the variation coefficient of the POC pointed to a difference between sampling sites. Conversely to POC, the values of mineral-associated organic carbon (MOC) were higher in the mounds than in the adjacent soil at both sampling depths; the base and center showed the highest difference between the mound and adjacent soil at both sampling distances. We did not find in the literature studies on the carbon of granulometric fractions of organic matter in epigeal mounds, or on the amount of this carbon in mound sections and the relationship of mound sections and the adjacent soil. However, we could observe that the average POC and MOC values in the soil adjacent to mounds were higher than those found in pastures without epigeal mounds (Carmo et al., 2012) in Red Latosols.

\subsection{Chemical fractionation of the soil organic matter (SOM)}

We observed that the carbon of the fulvic acid fraction (C-FAF) did not differ among mound sections (top, center, and base). However, we observed a significant difference $(\mathrm{P}<0.05)$ between mound sections and the adjacent soil at both sampling distances $(0.50$ and $1.50 \mathrm{~m}$ from the base), which were statistically similar to each other (Table 4). The values observed in the mounds were similar to those observed by Pinheiro et al. (2013) in a hilly landscape in spring. In summer, autumn, and winter, these authors observed a decrease in the values in mound sections, which equaled those of the adjacent soil in summer and winter. The values observed in the soil by Pinheiro et al. (2013) were smaller than ours, especially at $0.50 \mathrm{~m}$ from the mound.

The average carbon values in the humin fraction (C- HUM) did not differ significantly among mound sections (Table 4). Following the same pattern observed in the fulvic and humic fractions, the values in mounds
Table 4. Carbon of the fulvic acid fraction (FAF), humic acid fraction (HAF), and humin fraction (HUM) of termite mounds and adjacent soil in a pasture area.

\begin{tabular}{|cccc|}
\hline & C-FAF & C-HAF & C-HUM \\
\cline { 2 - 4 } Treatment & \multicolumn{3}{c}{ g kg-1 } \\
\hline Top & $5.91 \mathrm{a}$ & $13.71 \mathrm{a}$ & $23.83 \mathrm{a}$ \\
\hline Center & $4.34 \mathrm{a}$ & $10.88 \mathrm{a}$ & $23.33 \mathrm{a}$ \\
\hline Base & $5.07 \mathrm{a}$ & $10.69 \mathrm{a}$ & $26.07 \mathrm{a}$ \\
\hline $50 \mathrm{~cm}$ & $2.27 \mathrm{~b}$ & $3.30 \mathrm{~b}$ & $12.97 \mathrm{~b}$ \\
$150 \mathrm{~cm}$ & $1.5 \mathrm{~b}$ & $1.76 \mathrm{~b}$ & $9.83 \mathrm{c}$ \\
\hline CV\% & 17.14 & 17.90 & 9.58 \\
\hline & \multicolumn{3}{c}{ Depth $0.05-0.10 \mathrm{~m}$} \\
\hline Top & $5.91 \mathrm{a}$ & $13.71 \mathrm{a}$ & $23.83 \mathrm{a}$ \\
\hline Center & $4.34 \mathrm{a}$ & $10.88 \mathrm{a}$ & $23.33 \mathrm{a}$ \\
\hline Base & $5.07 \mathrm{a}$ & $10.69 \mathrm{a}$ & $26.07 \mathrm{a}$ \\
\hline $50 \mathrm{~cm}$ & $1.82 \mathrm{~b}$ & $2.48 \mathrm{~b}$ & $12.54 \mathrm{~b}$ \\
\hline $150 \mathrm{~cm}$ & $1.45 \mathrm{~b}$ & $2.08 \mathrm{~b}$ & $7.91 \mathrm{~b}$ \\
\hline CV\% & 14.37 & 16.30 & 10.41 \\
\hline
\end{tabular}

Mean values ( 7 replicate) followed by the same letter within columns are not significantly different according to Bonferroni test $(\mathrm{P}<0.05)$

differed from the adjacent soil at both depths and distances $(\mathrm{P}<0.05)$. In the study by Pinheiro et al. (2013) the values of humin fraction in the mounds in all seasons were higher than those observed in the present study, varying from $42.86 \mathrm{~g} \mathrm{~kg}^{-1}$ (autumn) to $68.06 \mathrm{~g} \mathrm{~kg}^{-1}$ (winter), whereas the values of the adjacent soil were more similar to those of the present study.

We observed a predominance of the humin fraction (C-HUM) compared to the humic and fulvic acid fractions both in mound sections and in the adjacent soil. This pattern was observed by other authors who studied the mound and adjacent soil in pastures (Pinheiro et al., 2013) and soils under different management regime (Fontana et al., 2006). The stable fractions of the SOM, denominated humic fractions, can be viewed as products of chemical and biological transformations of plant and animal matter, as well as of the activity of soil microorganisms (Primo et al., 2011), and they were considered indicators of processes and degree of humification of the SOM (Nascimento et al., 2010).

\section{CONCLUSIONS}

The studied epigeal termite mounds showed the same proportion of clay and sand on top and base sections, although there is higher clay content in mounds than in the adjacent soil. 
The builder species influenced the amount of organic matter and mineral-associated organic carbon.

The analysis of the chemical properties of the mounds showed that the concentrations of nutrients are higher in the mounds than in the adjacent soil.

\section{SUBMISSION STATUS}

Received: 17 mar., 2017

Accepted: 13 june, 2017

\section{CORRESPONDENCE TO}

\section{Marcos Gervasio Pereira}

Departamento de Solos, Universidade Federal Rural do Rio de Janeiro - UFRRJ, Rodovia BR 465, Km 7, CEP 23890-000, Seropédica, RJ, Brazil e-mail: mgervasiopereira01@gmail.com

\section{REFERENCES}

Adekayode FO, Ogunkoya MO. Comparative study of clay and organic matter content of termite mounds and the surrounding soils. In: Proceedings fo the IX African Crop Science Conference; 2009; South Africa. South Africa: African Crop Science Society; 2009. p. 379-384.

Benites VM, Madari B, Machado PLOA. Extração e fracionamento quantitativo de substâncias húmicas do solo: um procedimento simplificado de baixo custo. Rio de Janeiro: EMBRAPA Solos; 2003. 7 p. (Comunicado Técnico; no. 16).

Bezerra-Gusmão MA, Barbosa JRC, Barbosa MRV, Bandeira AG, Sampaio EVSB. Are nests of Constrictotermes cyphergaster (Isoptera, Termitidae) important in the C cycle in the driest area of semiarid caatinga in northeast Brazil? Applied Soil Ecology 2011; 47(1): 1-5. http://dx.doi. org/10.1016/j.apsoil.2010.11.003.

Brossard M, Lopez-Hernandez D, Lepage M, Leprun JC. Nutrient storage in soils and nests of mound-building Trinervitermes termites in Central Burkina Faso: consequences for soil fertility. Biology and Fertility of Soils 2007; 43(4): 437-447. http://dx.doi.org/10.1007/ s00374-006-0121-6.

Cambardella CA, Elliott ET. Particulate soil organic-matter changes across a grassland cultivation sequence. Soil Science Society of America Journal 1992; 56(3): 777-783. http:// dx.doi.org/10.2136/sssaj1992.03615995005600030017x.

Cancello EM. Revisão de Cornitermes Wasmann (Isoptera, Termitidae, Nasutitermitinae) [tese]. São Paulo: Instituto de Biociências, Universidade de São Paulo; 1989.

Cancello EM, Schlemmermeyer T. Isoptera. In: Brandão CRF, Cancello EM, editors. Biodiversidade do Estado de
São Paulo, Brasil: síntese do conhecimento ao final do século XX: invertebrados terrestres. São Paulo: FAPESP; 1999.

Carmo FF, Figueiredo CC, Ramos MLG, Vivaldi LJ, Araújo LG. Frações granulométricas da matéria orgânica em Latossolo sob plantio direto com gramineas. Bioscience Journal 2012; 28(3): 420-431.

Constantino R. Chave ilustrada dos gêneros de cupim (Insecta:Isoptera) que ocorrem no Brasil. Papéis Avulsos de Zoologia 1999; 40: 387-448.

Constantino R. The pest termites of South America: taxonomy, distribution and status. Journal of Applied Entomology 2002; 126(7-8): 355-365. http://dx.doi. org/10.1046/j.1439-0418.2002.00670.x.

Cunha HF, Morais PPAM. Relação espécie-área em cupinzeiros de pastagem, Goiânia-GO, Brasil. Entomo Brasilis. 2010; 3(3): 60-63. http://dx.doi.org/10.12741/ ebrasilis.v3i3.102.

Dangerfield JM, McCarthy TS, Ellery WN. The moundbuilding termite Macrotermes michaelseni as an ecosystem engineer. Journal of Tropical Ecology 1998; 14(4): 507-520. http://dx.doi.org/10.1017/S0266467498000364.

Donagema GK, Campos DVB, Calderano SB, Teixeira WG, Viana JHM, editors. Manual de métodos de análise de solos. 2. ed. Rio de Janeiro: Embrapa Solos; 2011. 230 p.

Donovan SE, Eggleton P, Dubbin WE, Batchelder M, Dibog L. The effect of a soil feeding termite, Cubitermes fungifaber (Isoptera: Termitidae) on soil properties: termites may be an important source of soil microhabitat heterogeneity in tropical forests. Pedobiologia 2001; 45(1): 1-11. http:// dx.doi.org/10.1078/0031-4056-00063.

Ferreira DF. SISVAR: um programa para análises e ensino de estatística. Revista Symposium 2008; 6: 36-41.

Fontana A, Pereira MG, Loss A, Cunha TJF, Salton JC. Atributos de fertilidade e frações húmicas de um Latossolo Vermelho no Cerrado. Pesquisa Agropecuária Brasileira 2006; 41(5): 847-853. http://dx.doi.org/10.1590/S0100204X2006000500018.

Holt JA, Lepage M. Termites and soil properties. In: Abe T, Higashi M, Bignell DE, editors. Termites: evolution, sociality, symbiosis, ecology. Dordrecht: Kluwer Academic Press; 2000. http://dx.doi.org/10.1007/978-94-017-3223-9_18.

Jouquet P, Dauber J, Lagerlöf J, Lavelle P, Lepage M. Soil invertebrates as ecosystemengineers: intended and accidental effects on soil and feedback loops. Applied Soil Ecology 2006; 32(2): 153-164. http://dx.doi.org/10.1016/j. apsoil.2005.07.004.

Jouquet P, Traoré S, Choosai C, Hartmann C, Bignell D. Influence of termites on ecosystem functioning.: ecosystem services provided by termites. European Journal of Soil Biology 2011; 47(4): 215-222. http://dx.doi.org/10.1016/j. ejsobi.2011.05.005.

Kaschuk G, Santos JCP, Almeida JA, Sinhorati DC, BertonJunior JF. Termite activity in relation to natural grassland 
soil attributes. Scientia Agrícola 2006; 63(6): 583-588. http://dx.doi.org/10.1590/S0103-90162006000600013.

Lavelle P, Bignell D, Lapage M. Soil function in changing world: the role of invertebrate ecosystems engineers. European Journal of Soil Biology 1997; 33: 159-193.

Lee KE, Wood TG. Termites and soils. New York: Academic Press; 1971.

Lima SS, Alves BJR, Aquino AM, Mercante FM, Pinheiro EFM, Sant'anna SAC et al. Relação entre a presença de cupinzeiros e a degradação de pastagens. Pesquisa Agropecuária Brasileira 2011; 46(12): 1699-1706. http:// dx.doi.org/10.1590/S0100-204X2011001200016.

Lima-Ribeiro MS, Pinto MP, Costa SS, Nabout JC, Rangel TFLVB, Melo TL et al. Associação de Constrictotermes cyphergaster Silvestri (Isoptera: Termitidae) com Espécies Arbóreas do Cerrado Brasileiro. Neotropical Entomology 2006; 35(1): 49-55. PMid:17352068. http://dx.doi. org/10.1590/S1519-566X2006000100007.

Mathews AGA. Studies on termites from the Mato Grosso State, Brazil. Rio de Janeiro: Academia Brasileira de Ciências; 1977.

Nascimento PC, Lani JL, Mendonça ES, Zoffoli HJO, Peixoto HTM. Teores e características da matéria orgânica de solos hidromórficos do Espírito Santo. Revista Brasileira de Ciência do Solo 2010; 34(2): 339-348. http://dx.doi. org/10.1590/S0100-06832010000200007.

Oliveira DE. Sistemática do grupo Velocitermes (Isopetera, Termitidae, Nasutitermitinae) [tese]. Brasília: Universidade de Brasília; 2013.

Oliveira LBT, Santos AC, Silva SP No, Silva JEC, Paiva JA. Alterações físicas e químicas do solo em virtude de construções termíticas no norte de Tocantins. Engenharia Agrícola 2012; 20: 118-130.

Oliveira MIL, Brunet D, Mitja D, Cardoso WS, Benito NP, Guimarães MF et al. Incidence of epigeal nest-building termites in Brachiaria pastures in the Cerrado. Acta Scientiarum: Agronomy 2011; 33(1): 181-185. http:// dx.doi.org/10.4025/actasciagron.v33i1.7075.
Pinheiro LBA, Pereira MG, Lima E, Correia MEF, Silva CF, Ebeling AG. Atributos Edáficos e de Termiteiros de Cupim-de-Montículo (Isoptera: Termitidae) em PinheiralRJ. Floresta e Ambiente 2013; 20: 510-520.

Primo DC, Menezes RSC, Silva TO. Substâncias húmicas da matéria orgânica do solo: uma revisão de técnicas analíticas e estudos no nordeste brasileiro. Scientia Plena. 2011; 7: 1-13.

Ribeiro JI Jr. Análises estatísticas no SAEG. Viçosa: Universidade Federal de Viçosa; 2001.

Rückamp D, Amelung W, Theisz N, Bandeira AG, Martius C. Phosphorus forms in Brazilian termite nests and soils: relevance of feeding guild and ecosystems. Geoderma 2010; 155(3-4): 269-279. http://dx.doi.org/10.1016/j. geoderma.2009.12.010.

Rückamp D, Martius C, Bornemann L, Kurzatkowski D, Naval LP, Amelung W. Soil genesis and heterogeneity of phosphorus forms and carbon below mounds inhabited by primary and secondary termites. Geoderma 2012; 170: 239-250. http://dx.doi.org/10.1016/j.geoderma.2011.10.004.

Santos HG, Jacomine PKT, Anjos LHC, Oliveira VA, Lumbreras JF, Coelho MR et al. Sistema Brasileiro de Classificação de Solos. 3. ed. Brasília: Embrapa; 2013.

Sarcinelli TS, Schaefer CEGR, Lynch LS, Arato HD, Viana JHM, Albuquerque MR Fo et al. Chemical, physical and micromorphological properties of termite mounds and adjacent soils along a toposequence in Zona da Mata, Minas Gerais State, Brazil. Catena 2009; 76(2): 107-113. http://dx.doi.org/10.1016/j.catena.2008.10.001.

Schaefer CER. Brazilian latosols and their B horizon microstructure as longterm biotic constructs. Australian Journal of Soil Research 2001; 39(5): 909-926. http://dx.doi. org/10.1071/SR00093.

Swift RS. Organic matter characterization. In: Sparks DL, Page AL, Helmke PA, Loeppert RH, Soltanpour PN, Tabatabai MA, et al., editors. Methods of soil analysis: chemical methods. Vol. 3. Madison: Soil Science Society of America, American Society of Agronomy; 1996. 